\title{
ВMJ Global Health Making the case: developing innovative adherence solutions for the treatment of tuberculosis
}

\author{
Malvika Verma, ${ }^{\oplus 1}$ Jennifer Furin, ${ }^{2}$ Robert Langer, ${ }^{3}$ Giovanni Traverso ${ }^{\oplus, 4,5}$
}

\begin{abstract}
To cite: Verma M, Furin J, Langer R, et al. Making the case: developing innovative adherence solutions for the treatment of tuberculosis. BMJ Glob Health 2019;4:e001323. doi:10.1136/ bmjgh-2018-001323
\end{abstract}

Handling editor Seye Abimbola

Received 24 November 2018 Revised 10 January 2019 Accepted 12 January 2019

Check for updates

(C) Author(s) (or their employer(s)) 2019. Re-use permitted under CC BY. Published by BMJ.

'Department of Biological Engineering and Koch Institute for Integrative Cancer Research, Massachusetts Institute of Technology, Cambridge, Massachusetts, USA ${ }^{2}$ Department of Global Health and Social Medicine, Harvard Medical School, Boston, Massachusetts, USA ${ }^{3}$ Department of Chemical Engineering and Koch Institute for Integrative Cancer Research, Massachusetts Institute of Technology, Cambridge, Massachusetts, USA ${ }^{4}$ Division of Gastroenterology, Brigham and Women's Hospital, Harvard Medical School, Boston, Massachusetts, USA ${ }^{5}$ Department of Mechanical Engineering, Massachusetts Institute of Technology, Cambridge, Massachusetts, USA

Correspondence to Dr Giovanni Traverso; ctraverso@bwh.harvard.edu
Tuberculosis (TB), which claims the lives of over 3500 people every day, is the world's leading killer among infectious diseases. ${ }^{1}$ According to the WHO, 10 million people developed TB in 2017 with a global economic burden amounting to $\$ 12$ billion annually. ${ }^{12}$ Furthermore, TB is the most significant pathogen in the global antimicrobial resistance (AMR) crisis. ${ }^{3}$ Unless radical action is taken, drug-resistant strains of TB will account for $25 \%$ of the AMR-related deaths and cost the global economy $\$ 16.7$ trillion by the year $2050 .^{3}$ TB treatment is challenging with its prolonged and frequent dosing regimen that may be associated with challenging side effects. ${ }^{4}$ While significant work has been done to support adherence among people living with TB who are on treatment-including direct observation of therapy and provision of socioeconomic support-there has been limited focus on translation of how the medications themselves and their administration might be altered to improve adherence.

Technologies that enable extended drug release of medication have the potential to overcome patient non-adherence to long and frequent dosing regimens. Long-acting formulations are being implemented for the reduction in the frequency of HIV treatment administration, though they require injections which can be uncomfortable for patients. ${ }^{5}$ Instead, a long-acting oral dosage would be very attractive and improve adherence to treatment, as the oral route of drug delivery is preferred by patients. Novel ingestible gastric-resident systems for extended controlled drug release are being developed by several groups (including the Langer and Traverso laboratories) for antimalarials and antiretrovirals. $^{67}$

The challenge with designing drug depot systems for TB treatment is to balance the ease and safety of administration with the accommodation of gram-level quantities of
TB drugs which have low potency. Under the current regimen during the intensive phase, a $60 \mathrm{~kg}$ patient with TB swallows almost 100 $\mathrm{g}$ of antibiotics in 1 month. ${ }^{8}$ One potential area of development which could aid in improved delivery include inhaled or orally delivered nanocarriers which have been designed for extended release of existing TB drugs, although they have yet to be tested in large animal models. ${ }^{9}{ }^{10}$ Considering that bedaquiline is the first new approved TB drug in more than 40 years and the dearth of others in the TB drug development pipeline to overcome challenges of the current drugs, nanotechnology can provide an enormous impact with design of novel and targeted delivery systems for existing drugs. ${ }^{11}$ Ideally, these nanomaterial-based systems would be inexpensive, easy to administer, minimise side effects and reduce the required dosing frequency to improve patient adherence.

Developments in depot systems and more potent drugs can also improve treatment of children, who comprised 1 million $(10 \%)$ of the new TB cases in 2017. ${ }^{1}$ Children face challenges in adhering to their treatments due to the difficulty in swallowing pills, bad taste of crushed tablets and aversion to needles. ${ }^{12}$ Therefore, it is difficult for caregivers to ensure the child is achieving the correct dosage while minimising toxic effects. A recent study in Mozambique found that over $30 \%$ of children do not adhere to the WHO recommended regimen. ${ }^{13}$ Finally, childfriendly first-line TB formulations became available through the Global Drug Facility. ${ }^{12}$ Optimising second-line drugs for drug-resistant TB in children is much further behind, and there are currently few drug depot systems available to simplify treatment and improve adherence. ${ }^{1415}$ Notably, a paediatric dispersible formulation of delaminid may be promising and is currently being assessed in clinical trials. $^{16}$ 
Table 1 Advantages and disadvantages of different routes of administration for drug delivery formulations relevant to infectious diseases

\begin{tabular}{|c|c|c|c|c|}
\hline $\begin{array}{l}\text { Route of } \\
\text { administration }\end{array}$ & $\begin{array}{l}\text { Site of } \\
\text { absorption }\end{array}$ & $\begin{array}{l}\text { Examples of } \\
\text { drug delivery } \\
\text { formulations }\end{array}$ & Advantages & Disadvantages \\
\hline \multirow[t]{3}{*}{ Oral (per os) } & \multirow[t]{3}{*}{$\begin{array}{l}\text { Along } \\
\text { gastrointestinal } \\
\text { tract }\end{array}$} & $\begin{array}{l}\text { Ingestible gastric } \\
\text { resident systems } \\
\text { for antimalarials and } \\
\text { antiretrovirals }^{67}\end{array}$ & $\begin{array}{l}\text { 1. Non-invasive. } \\
\text { 2. Can be self-administered. } \\
\text { 3. Preferred by patients. }\end{array}$ & \multirow{3}{*}{$\begin{array}{l}\text { 1. Non-adherence due to } \\
\text { frequent dosing for high pill } \\
\text { burden of TB treatment. } \\
\text { 2. Chemical environment is } \\
\text { harsh. } \\
\text { 3. Degraded by first pass- } \\
\text { metabolism. }\end{array}$} \\
\hline & & $\begin{array}{l}\text { Solid lipid } \\
\text { nanoparticles of TB } \\
\text { treatment }^{9}\end{array}$ & & \\
\hline & & $\begin{array}{l}\text { Paediatric } \\
\text { dispersible tablets } \\
\text { for Coartem and } \\
\text { delaminid }^{1617}\end{array}$ & & \\
\hline Rectal & Rectal mucosa & $\begin{array}{l}\text { Rectal artesunate } \\
\text { suppositories for } \\
\text { the prereferral } \\
\text { management of } \\
\text { severe malaria }^{19}\end{array}$ & $\begin{array}{l}\text { 1. Useful for unconscious } \\
\text { patients and children. } \\
\text { 2. No need to taste-mask drug. } \\
\text { 3. Partial avoidance of first-pass } \\
\text { metabolism. }\end{array}$ & $\begin{array}{l}\text { 1. Absorption can be slow or } \\
\text { erratic. } \\
\text { 2. Frequent application to match } \\
\text { gram-level dosing of TB } \\
\text { treatment. } \\
\text { 3. Prone to irritation of rectal } \\
\text { mucosa. }\end{array}$ \\
\hline
\end{tabular}

\section{Parental}

Intravenous

Veins, systemic Artemisinin bioavailable nanoformulation ${ }^{20}$
1. Achieves $100 \%$ bioavailability. 1. Invasive.

2. Reproducible.

2. Requires trained personnel.

3. Prone to infection.

4. Frequent injections to match gram-level dosing of TB treatment.

\begin{tabular}{|c|c|c|c|c|}
\hline Intramuscular & $\begin{array}{l}\text { Skeletal } \\
\text { muscle }\end{array}$ & $\begin{array}{l}\text { Nanoparticles } \\
\text { of rilpivirine and } \\
\text { cabotegravir for HIV } \text { treatment }^{21} \\
\text { Atovaquone solid } \\
\text { drug nanoparticles } \\
\text { for malaria } \\
\text { prophylaxis }^{22}\end{array}$ & $\begin{array}{l}\text { 1. Rapid absorption. } \\
\text { 2. Avoids first-pass metabolism. }\end{array}$ & $\begin{array}{l}\text { 1. Invasive. } \\
\text { 2. Limited volume for injection, } \\
\text { so may not match gram-level } \\
\text { dosing of TB treatment. } \\
\text { 3. Risk of nerve damage. }\end{array}$ \\
\hline Subcutaneous & $\begin{array}{l}\text { Into tissue } \\
\text { between } \\
\text { dermis and } \\
\text { muscle }\end{array}$ & $\begin{array}{l}\text { Ultra-long-acting } \\
\text { dolutegravir implant } \\
\text { for HIV treatment } \\
\text { and prevention } \\
\text { Nanochannel } \\
\text { implant with } \\
\text { refillable feature for } \\
\text { delivery of tenofavir } \\
\text { diphosphate }^{24}\end{array}$ & $\begin{array}{l}\text { 1. Slow absorption and } \\
\text { distribution compared with } \\
\text { intramuscular. } \\
\text { 2. Avoids first-pass metabolism. }\end{array}$ & $\begin{array}{l}\text { 1. Invasive. } \\
\text { 2. Limited volume for injection, } \\
\text { so may not match gram-level } \\
\text { dosing of TB treatment. } \\
\text { 3. Risk of tissue damage. }\end{array}$ \\
\hline
\end{tabular}


Table 1 Continued

\begin{tabular}{|c|c|c|c|c|}
\hline $\begin{array}{l}\text { Route of } \\
\text { administration }\end{array}$ & $\begin{array}{l}\text { Site of } \\
\text { absorption }\end{array}$ & $\begin{array}{l}\text { Examples of } \\
\text { drug delivery } \\
\text { formulations }\end{array}$ & Advantages & Disadvantages \\
\hline Intradermal & $\begin{array}{l}\text { Into dermis } \\
\text { layer }\end{array}$ & $\begin{array}{l}\text { Intradermal } \\
\text { injections of HIV } \\
\text { DNA vaccines using } \\
\text { needle-free injector }\end{array}$ & $\begin{array}{l}\text { 1. Faster absorption and } \\
\text { distribution compared with } \\
\text { subcutaneous. } \\
\text { 2. Avoids first-pass metabolism. } \\
\text { 3. Higher immune responses for } \\
\text { vaccinations. }\end{array}$ & $\begin{array}{l}\text { 1. Invasive. } \\
\text { 2. Limited volume for injection, } \\
\text { so may not match gram-level } \\
\text { dosing of TB treatment. } \\
\text { 3. Risk of tissue damage. }\end{array}$ \\
\hline Intrathecal & $\begin{array}{l}\text { Into } \\
\text { cerebrospinal } \\
\text { fluid }\end{array}$ & $\begin{array}{l}\text { Intrathecal } \\
\text { administration } \\
\text { of isoniazid for } \\
\text { TB meningitis } \\
\text { treatment }^{26}\end{array}$ & $\begin{array}{l}\text { 1. Bypasses blood-brain barrier. } \\
\text { 2. Local effect on meninges or } \\
\text { cerebrospinal axis. }\end{array}$ & $\begin{array}{l}\text { 1. Invasive. } \\
\text { 2. Limited volume for injection, } \\
\text { so may not match gram-level } \\
\text { dosing of TB treatment. } \\
\text { 3. Risk of tissue damage. }\end{array}$ \\
\hline Intra-articular & Into joint space & $\begin{array}{l}\text { Intra-articular } \\
\text { streptomycin in } \\
\text { tuberculosis of the } \\
\mathrm{knee}^{27}\end{array}$ & $\begin{array}{l}\text { 1. Avoids first-pass metabolism. } \\
\text { 2. Local effect on joint. }\end{array}$ & $\begin{array}{l}\text { 1. Invasive. } \\
\text { 2. Limited volume for injection, } \\
\text { so may not match gram-level } \\
\text { dosing of TB treatment. } \\
\text { 3. Risk of tissue damage. }\end{array}$ \\
\hline Inhalation & $\begin{array}{l}\text { Mucosal } \\
\text { surfaces for } \\
\text { the lung }\end{array}$ & $\begin{array}{l}\text { Nebulised solid lipid } \\
\text { nanoparticles for TB } \\
\text { treatment } \\
\text { Nano microparticle } \\
\text { vaccine formulation } \\
\text { for } \text { TB }^{28}\end{array}$ & $\begin{array}{l}\text { 1. Non-invasive. } \\
\text { 2. Large surface area for } \\
\text { absorption. } \\
\text { 3. Avoids first-pass metabolism. } \\
\text { 4. Targets where TB bacteria } \\
\text { reside. }\end{array}$ & $\begin{array}{l}\text { 1. Variability in dosing depends } \\
\text { on patient technique. } \\
\text { 2. Requires portable, cheap and } \\
\text { easy to operate devices for } \\
\text { administration. } \\
\text { 3. Frequent inhalation to be } \\
\text { compatible with gram-level } \\
\text { dosing of TB treatment. }\end{array}$ \\
\hline Transdermal & Through skin & $\begin{array}{l}\text { Film of HIV inhibitor } \\
\text { IQP- } 0410^{29} \\
\text { Solid dispersions } \\
\text { of artemisinin for } \\
\text { malaria treatment } \\
30\end{array}$ & $\begin{array}{l}\text { 1. Non-invasive. } \\
\text { 2. Can be self-administered. } \\
\text { 3. Avoids first-pass metabolism. }\end{array}$ & $\begin{array}{l}\text { 1. Transport barriers for many } \\
\text { drugs. } \\
\text { 2. Slow absorption. } \\
\text { 3. May require frequent } \\
\text { administration or very large } \\
\text { patch to match gram-level } \\
\text { dosing of TB. }\end{array}$ \\
\hline $\begin{array}{l}\text { Topical: ocular, } \\
\text { nasal, skin }\end{array}$ & $\begin{array}{l}\text { At site of } \\
\text { application }\end{array}$ & $\begin{array}{l}\text { Topical treatment of } \\
\text { cutaneous TB using } \\
\text { oil nanoemulsions }^{31}\end{array}$ & $\begin{array}{l}\text { 1. Non-invasive. } \\
\text { 2. Can be self-administered. } \\
\text { 3. Rapid absorption. } \\
\text { 4. Local effect, so avoids side } \\
\text { effects. }\end{array}$ & $\begin{array}{l}\text { 1. Transport barriers for many } \\
\text { drugs. } \\
\text { 2. May require frequent } \\
\text { administration to match gram- } \\
\text { level dosing of TB. }\end{array}$ \\
\hline Intravaginal & $\begin{array}{l}\text { Mucosal } \\
\text { surfaces lining } \\
\text { the vagina }\end{array}$ & $\begin{array}{l}\text { Monthly vaginal } \\
\text { rings for dapivirine, } \\
\text { an HIV drug } \\
\text { Topical tenofovir } \\
\text { disoproxil fumarate } \\
\text { nanoparticles }\end{array}$ & $\begin{array}{l}\text { 1. Reduce frequency of dosing. } \\
\text { 2. Avoids first-pass metabolism. } \\
\text { 3. Dense network of blood } \\
\text { vessels in vagina, so ideal for } \\
\text { systemic drug absorption. }\end{array}$ & $\begin{array}{l}\text { 1. Invasive. } \\
\text { 2. Requires trained personnel. } \\
\text { 3. Implants may require frequent } \\
\text { dosing to match gram-level } \\
\text { dosing of TB treatment. }\end{array}$ \\
\hline
\end{tabular}

TB, tuberculosis.

TB treatment adherence challenges contribute to poor health outcomes, prolonged infectiousness, drug resistance, relapse and death. While most adherence work has focused on changing the behaviours of people taking TB medications, there has been little work done exploring how the medications might be altered to improve the experience of people living with TB. We challenge global health agencies and funding bodies to prioritise patientfriendly interventions that improve adherence by incentivising more collaborations between clinicians, engineers and patients. These include development of technologies to facilitate dose administration with more potent drugs or novel drug depot systems, while addressing the needs of vulnerable populations such as children. We recognise that preferences and adoption rates for drug delivery modalities, such as inhalable nanotechnology systems, transdermal patches, liquid formulations and gastric resident systems vary across patient groups (table 1). Increased interaction among physicians, engineers and the TB community stands to facilitate innovative solutions 
to maximise delivery of medicine to patients and transform the treatment of infectious diseases.

Contributors MV, JF, RL and GT participated in the writing, reviewing and editing of the article.

Funding This work was funded in part by the Bill and Melinda Gates Foundation Grants OPP1096734 and OPP1139927, the NIH Grant EB000244, and the MIT Tata Center Grant, NSF Fellowship to MV.

Competing interests MV, RL and GT are co-inventors on multiple patent applications describing large dose gastric drug delivery systems which can be applied to treating TB: US Patent Applications \#62/678,439, \#62/678,471 and \#62/678,492. RL and GT both report personal fees from Lyndra Inc, outside the submitted work; In addition, RL and GT have a patent PCT/US15-35423 - Residence Structures and Related Methods pending to Lyndra, a patent PCT/US15/35425 - Enteric Elastomers pending to Lyndra, and a patent PCT/ US15/35429 - Self-Assembled Residence Devices and Related Methods pending to Lyndra.

Patient consent for publication Not required.

Provenance and peer review Not commissioned; externally peer reviewed. Data sharing statement № additional data are available.

Open access This is an open access article distributed in accordance with the Creative Commons Attribution 4.0 Unported (CC BY 4.0) license, which permits others to copy, redistribute, remix, transform and build upon this work for any purpose, provided the original work is properly cited, a link to the licence is given, and indication of whether changes were made. See: https://creativecommons.org/ licenses/by/4.0/.

\section{REFERENCES}

1. World Health Organization, 2018. Global tuberculosis report 2018. Geneva, Switzerland. Available: http://apps.who.int/iris/bitstream/ handle/10665/274453/9789241565646-eng.pdf

2. Kim JY, Shakow A, Castro A, 2003. The burden of tuberculosis: economic burden (2). Tuberculosis control. Available: http://www. who.int/trade/distance_learning/gpgh/gpgh3/en/index7.html [Accessed 2 Apr 2017].

3. O'Neill J, 2016. Tackling drug-resistant infections globally: final report and recommendations. London, United Kingdom. Available: https://amr-review.org/sites/default/files/160518_Final paper_with cover.pdf [Accessed 20 Jan 2018].

4. Sabaté E, 2003. Adherence to long-term therapy: evidence for action. Geneva, Switzerland. Available: http://apps.who.int/iris/ bitstream/handle/10665/42682/9241545992.pdf

5. Dolgin E. Long-acting HIV drugs advanced to overcome adherence challenge. Nat Med 2014;20:323-4.

6. Bellinger AM, Jafari M, Grant TM, et al. Oral, ultra-long-lasting drug delivery: application toward malaria elimination goals. Sci. Transl. Med. 2016:8:365ra157-365.

7. Kirtane AR, Abouzid O, Minahan D, et al. Development of an oral once-weekly drug delivery system for HIV antiretroviral therapy. Nat Commun 2018;9:1-12.

8. World Health Organization. Treatment of tuberculosis: guidelines. 4th edn. Geneva, Switzerland, 2010.

9. Pandey R, Sharma S, Khuller GK. Oral solid lipid nanoparticle-based antitubercular chemotherapy. Tuberculosis 2005;85:415-20.

10. Pandey R, Khuller GK. Solid lipid particle-based inhalable sustained drug delivery system against experimental tuberculosis. Tuberculosis 2005:85:227-34.

11. Cohen J. Approval of Novel TB Drug Celebrated--With Restraint. Science 2013;339:130.
12. World Health Organization, 2018. Fixed-dose combinations for the treatment of TB in children. Geneva, Switzerland. Available: http:// www.who.int/tb/areas-of-work/children/

13. Lopez-Varela E, Sequera VG, García-Basteiro AL, et al. Adherence to childhood tuberculosis treatment in Mozambique. J Trop Pediatr 2017;63:87-97.

14. Clayden P, Collins S, Frick M et al, 2016. 2016 Pipeline Report HIV \& TB. Available: http://i-base.info/htb/wp-content/uploads/2016/07/ 2016-Pipeline-Report.pdf

15. Furin J, Tommasi M, Garcia-Prats AJ. Drug-resistant tuberculosis: will grand promises fail children and adolescents? Lancet Child Adolesc Heal 2018;2:237-8.

16. Harausz EP, Garcia-Prats AJ, Seddon JA, et al. New and repurposed drugs for pediatric multidrug-resistant tuberculosis. practice-based recommendations. Am J Respir Crit Care Med 2017;195:1300-10.

17. Bassat Q, Ogutu B, DJimde A, et al. Development of a pediatric formulation for treatment of P. falciparum malaria: Coartem ${ }^{\circledR}$ (artemether-lumefantrine) Dispersible. Malar J 2014;13(Suppl 1):P7

18. Salman S, Bendel D, Lee TC, et al. Pharmacokinetics of a novel sublingual spray formulation of the antimalarial drug artemether in African children with malaria. Antimicrob Agents Chemother 2015;59:3208-15.

19. Gomes MF, Faiz MA, Gyapong JO, et al. Pre-referral rectal artesunate to prevent death and disability in severe malaria: a placebo-controlled trial. Lancet 2009;373:557-66.

20. Ibrahim N, Ibrahim H, Sabater AM, et al. Artemisinin nanoformulation suitable for intravenous injection: preparation, characterization and antimalarial activities. Int J Pharm 2015;495:671-9.

21. Margolis DA, Gonzalez-Garcia J, Stellbrink H-J, et al. Long-acting intramuscular cabotegravir and rilpivirine in adults with HIV-1 infection (LATTE-2): 96-week results of a randomised, open-label, phase 2B, non-inferiority trial. Lancet 2017;390:1499-510.

22. Bakshi RP, Tatham LM, Savage AC, et al. Long-acting injectable atovaquone nanomedicines for malaria prophylaxis. Nat Commun 2018;9:1-8

23. Kovarova M, Benhabbour SR, Massud I, et al. Ultra-long-acting removable drug delivery system for HIV treatment and prevention. Nat Commun 2018;9.

24. Chua CYX, Jain P, Ballerini A, et al. Transcutaneously refillable nanofluidic implant achieves sustained level of tenofovir diphosphate for HIV pre-exposure prophylaxis. J Control Release 2018;286:315-25.

25. EOV I, Kroidl A, Munseri PJ, et al. Optimizing the immunogenicity of HIV prime-boost DNA-MVA-rgp140/GLA vaccines in a phase II randomized factorial trial design. PLoS One 2018;13:1-19.

26. Nakatani $\mathrm{Y}$, Suto $\mathrm{Y}$, Fukuma K, et al. Intrathecal isoniazid for refractory tuberculous meningitis with cerebral infarction. Intern. Med. 2017:56:953-7.

27. Ahern RT, Arden GP. Intra-articular streptomycin in tuberculosis of the knee. BMJ 1952;1:466-8.

28. Garcia-Contreras L, Wong Y-L, Muttil P, et al. Immunization by a bacterial aerosol. Proc Natl Acad Sci 2008;105:4656-60.

29. Ham AS, Lustig W, Yang L, et al. In vitro and ex vivo evaluations on transdermal delivery of the HIV inhibitor IQP-0410. PLOS ONE 2013;8:e75306-11.

30. Shahzad Y, Sohail S, Arshad MS, et al. Development of solid dispersions of artemisinin for transdermal delivery. Int J Pharm 2013;457:197-205.

31. Burger C, Aucamp M, du Preez J, et al. Formulation of natural oil nano-emulsions for the topical delivery of clofazimine, artemisone and decoquinate. Pharm Res 2018;35.

32. Baeten JM, Palanee-Phillips T, Brown ER, et al. Use of a vaginal ring containing dapivirine for HIV-1 prevention in women. Obstet Gynecol Surv 2016;71:466-8.

33. Srinivasan P, Moss JA, Gunawardana M, et al. Topical delivery of tenofovir disoproxil fumarate and emtricitabine from Pod-Intravaginal rings protects macaques from multiple SHIV exposures. Plos One 2016;11:e0157061-17 